\title{
Studies on floristic diversity of some endangered plant species from Western Ghats of Nasik district, Maharashtra
}

Sangale M. P. ${ }^{1}$, Kshirsagar S. R. ${ }^{2}$ and Shinde, H. P. ${ }^{*}$

1,3 Department of Botany, K. V. N. Naik Arts, Commerce and science College Nashik, Maharashtra, India ${ }^{2}$ Post Graduate Department of Botany. S.S.V.P.S.L.K. Dr. P.R. Ghogrey, Science College, Dhule, Maharashtra, India *Corresponding Author : shindehemant79@gmail.com

\section{ABSTRACT}

\section{Article Info}

Volume 8, Issue 2

Page Number : 278-286

\section{Publication Issue}

March-April-2021

\section{Article History}

Accepted : 20 March 2021

Published : 28 March 2021
The present study deals with floristic diversity and taxonomy along with the observations with respect to precise locations, flowering, fruiting period and potential threats of some endangered plant species of Western Ghats in Nasik district of Maharashtra. Total 30 endangered plant species belonging to 14 families; were recorded during an extensive field surveys and botanical excursions; conducted from 2018 to 2020 at several places mainly forest pockets and hilly regions from Nasik tehsils like Sinnar, Trymbakeshwar, Igatpuri, Chandwad, Kalwan etc. The occurrence of endangered plant species focusing their floristic and taxonomical aspects were monitored continuously so as know the current status of these species in the study area. It was observed that the probable reasons for consistent decrease in number of endangered plant species in the study area; are destruction of natural habitats due to increasing illegal acquisition of forest land, massive deforestation and urbanization. The present study thus highlights an effective monitoring and conservation strategy to be adopted for the sustainable use of endangered plants.

Keywords : Endangered Plants, Nasik, Western Ghats.

\section{INTRODUCTION}

Western Ghats is a hot-spot of plant biodiversity. Many endangered and threatened plants are found growing naturally in this area. The Western Ghat has $6 \%$ of India's landmass with $30 \%$ of plants and animals. There are specific patches in the Western Ghats that are of special significance as they constitute habitats of endangered species several of which are on IUCNs endangered species list. (Gunawardene et al. 2007; Bharucha et.al.;2010).

The plant species which were abundant previously in this region are being exploited consistently. Several species of plants are already extinct or on verge of extinction. The alarming rate of loss of biodiversity in Western Ghats is a major concern today. Many plant species are under constant anthropogenic pressure on account of their economic value. With population explosion, shifting cultivation, grazing, encroachment

Copyright: (C) the author(s), publisher and licensee Technoscience Academy. This is an open-access article distributed under the terms of the Creative Commons Attribution Non-Commercial License, which permits unrestricted non-commercial use, distribution, and reproduction in any medium, provided the original work is properly cited 
for agriculture, extraction of timber and fuel wood, spread of invasive alien weeds, and selective removal of certain species such as the medicinal plants have all resulted in clearing of the natural vegetation. (Rao; 2019)

An endangered species is one, which is in danger of extinction throughout all or of a significant portion of its range.(Bryde, 1979; Smith 1980; Nayar and Sastry; 1990). Many medicinal plant species have gone into threatened category due to their increased demand and these need to be assessed as endangered or even critically endangered or have to be put under legal protection. (Mehta et.al.; 2020). Some species are critically endangered in the wild and therefore it is essential to take urgent steps to conserve the wealth of medicinal plants. The present investigation was undertaken in order to survey and document endangered plant species of Western Ghats of Nasik district which is found to be under huge human pressure due to which numbers of species are being included under rare endangered and threatened (RET) category. In recent years; increasing loss of biodiversity has created serious threat to the survival of mankind. Harvesting, grazing, shifting cultivation and uprooting of plant species for the purpose of food, fodder and medicines by tribal and local people are found the major cause for their threats. Most part of Western Ghats especially northern Western Ghats harbors dry habitats including coastal plains (Devgad, Malvan, Konkan), lateritic plateaus (Ratnagiri), high-elevation plateaus (Kaas, Gothane), steep rocky areas (Gaganbawda, Kumbharli Ghat), dry deciduous forests (Satara, Wai), and rocky mountain tops (Nashik). This underlines the need for exhaustive floristic explorations to understand their actual distribution (Surveswaran et.al.;2020). Though the several efforts are underway worldwide to conserve critically endangered species, the efforts in India are far too few that might be due to expensive and timeconsuming species recovery programmes and lack of focus. However; long-term monitoring involving periodical assessment of the population changes of the species need to be developed so as to potentially delist them from the red-list. (Ravikanth and Aravind et.al.;2018).

\section{METHODS AND MATERIAL}

The Nasik district is located between latitudes $19^{\circ} 35^{\prime}$ and $20^{\circ} 50^{\prime}$ and the longitudes $73^{\circ} 30^{\prime}$ and $74^{\circ} 55^{\prime}$ and extends over an area of 15,582 sq.km. The forests of the district cover an area of 3,446.28 sq. km. The vegetation of the Nashik region is semi-moist to dry deciduous forest type but mixed with the members of thorny stunted plants in moderate rainfall zone (600$1000 \mathrm{~mm}$ ). The tree vegetation is sparse with low density and stunted growth mainly restricted to valleys and slopes. (www.nashiknic.in). The study area i.e. Western Ghats of Nasik district includes mainly forest pockets and outskirts of Peith, Kalwan, Surgana, Baglan, Sinnar, Chnadwad and Trymbakeshwar tehsils. (Fig.1).

The collection, identification and documentation of endangered plant species observed during an extensive survey from the months of July 2015 to December 2020. The field data such as distribution, number of individuals, habit and habitat was recorded and documented as photographs also. The collected specimens were identified by referring to various floras like flora of presidency of Bombay (Cooke;1958), flora of Nasik (Lakshminarasimhan and Sharma), flora of Dhule and Nandurbar districts (Patil;2003). The nomenclature, IUCN category of collected plant species has been adapted and list of observed plant species has been updated according to the available online resources and databases of ICBN, IUCN red list. (www.iucnredlist.org.). (Ahmedullah and Nayar; 1987; Nayar and Sastry; 1987-1990; Mishra and Singh; 2001). 


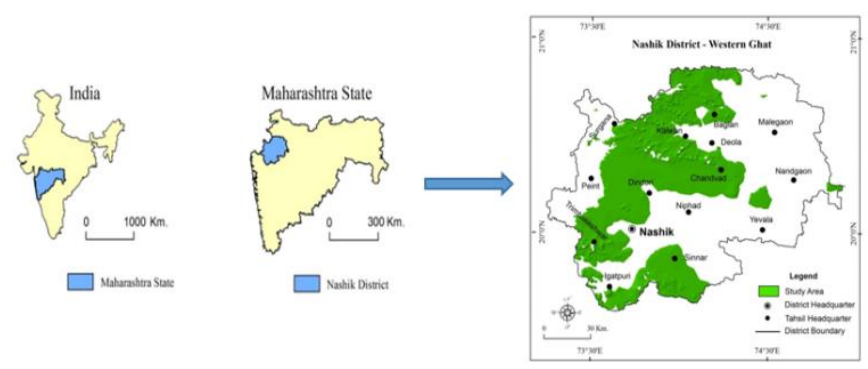

Fig.1. location map showing study area

\section{RESULTS AND DISCUSSION}

The results of the study have revealed that 30 plant species belonging to 14 families 19 genera, 28 species and 2 varieties. Of these; 22 plant species were herbs, 04 were twiners 2 were shrubs and one climber one was an epiphyte. (Fig.2-B). Among these; majority of the herbs and twiners were dicot plants and few were monocots. (Fig.2-C). In the present study; the maximum number of endangered plant species were found to be belonging to the family Apocynaceae which covered total of 8 species, followed by Liliaceae, and Orchidaceae with total of 6 and 4 species respectively (Table 1, Fig. 2-A). Present study has revealed that in the area there were 30 endangered flowering plant species found to be under endangered category according IUCN; 1993, and 2000 guidelines. Of these; the dominance of plant families like Apocynaceae has also been reported in wide-ranging tropical forests of Western Ghats and is also evident in this study. Sukumaran and Raj;2007, Sarvalingam and Rajendran;2016). The possible causes of these plant species getting endangered are illegal trade, overexploitation, habitat loss, habitat fragmentation, over grazing, soil erosion, climate changes, loss of reproduction, low seed germination etc. A major concern is the conservation of outlying hill ranges, low plateaus or isolated hills and elevated areas which can have immense bioresources with endemic and endangered ground flora. (Bharucha et.al.;2010). Even though the species Gloriosa superba L. was reported as an endangered species according to IUCN reports and earlier studies; it was observed as quite abundant during the present studies. (Sarvalingam and Rajendran;2016). Plant species like Ceropegia mahabalei, Ceropegia sahyadrica, Chlorophytum bharuchii, Sonerila scapigera, Begonia phrixophylla, Bigonia trichocarpa etc. were found to be growing mostly on dry cliffs and hill passes of Western Ghats which are known to support ecologically specialized microhabitat to some vascular plant species. (Datar and Watve; 2018). Also, during the present study; it was observed that some plant families have been represented by few endangered or critically endangered and newly added pant species to Nasik flora; especially in case of family Apocynaceae represented by total 8 species of genus Ceropegia only; Liliaceae by genus Chlorophytum (03 species), similarly Orchidaceae and Bigoniacae have been represented by genera like Habenaria and Begonia (02 species each) respectively. (Garud and Shinde 2018). However; it was found that most of these species especially Ceropegia hirsuta, Ceropegia lawii Gloriosa superba, Canscora diffusa etc. can be cultivated and conserved through reintroduction in the college garden and in particular reserved areas. There is however, now an urgent need to evolve a sound strategy for the management and conservation of these plants on a long-term basis. To evolve suitable strategies for conservation the domestic cultivation of endangered plants must be adopted.

\section{REFERENCES}

[1]. Ahmedullah, M. and Nayar, M.P. 1987. Endemic plants of the Indian region I. Peninsular India. Botanical Survey of India, Calcutta.

[2]. Aravind, N. A., Manjunath1, J., Rao,D., Ganeshaiah, K. N., Shaanker, R. U. and Vanaraj, G. 2005. Are red-listed species threatened? A comparative analysis of red-listed and non-redlisted plant species in the Western Ghats, India. Current Science, Vol. 88, No. 2. 
[3]. Bryde, M.B. 1979. Information needed to use the endangered species act for plant conservation, (Geographical data organization, rare plant conservation, New York).

[4]. Cooke, T. 1958. The flora of the presidency of Bombay, Calcutta: Botanical Survey of India. Volumes 1-3. 615- 649 pp.

[5]. Datar, M.N. and Watve, A.V 2018. Vascular plant assemblage of cliffs in northern Western Ghats, India. Journal of Threatened Taxa.10(2): 11271-11284;

http://doi.org/10.11609/jott.3611.10.2. 1127111284.

[6]. Erach Bharucha, Shamita Kumar Parag, Khatawkar Anand Shinde, Kranti Yardi, Jyoti Prabha, Karishma Mehta, Ganesh Zende, Anwesha Borethakur, Rashi Khare and Vidya Pujari. 2010. Current ecological status and identification of potential ecologically sensitive areas in the northern Western Ghats. Status Report, Institute of Environment Education and Research Bharti Vidyapeeth (BVIEER) Deemed University, Pune, Maharashtra.

[7]. Gunawardene, N. R, A. E.D Daniels, I. Gunatilleke, C. V. S. Gunatilleke, P. V. Karunakaran, K. G Nayak, S. Prasad, et al. 2007. A brief overview of the Western Ghats- Sri Lanka biodiversity hotspot. Current Science 93, no. 11: 1567-1572.

[8]. IUCN 2001. IUCN Red list categories and criteria. Version 3.1. Accessible athttp://www.iucnredlist.org/technicaldocuments/categories-and-criteria/2001categories-criteria\#categories.

[9]. Kshirsagar S. R. (2012). Ex-Situ Conservation of Rare, Endangered and Lost Plants of South Delhi and Aravalli Hilly Ranges. Life Science Liflets, 1:49, 54.

[10]. Kshirsagar S. R. and Patil D. A. (2008). Flora of Jalgaon District, Maharashtra, (Bishen Singh Mahendra Pal Singh, Deheradun, India).
[11]. Lakshminarasimhan, P. and Sharma, B.D. 1991. Flora of Nasik, Botanical Survey of India, Calcutta, India).

[12]. Mehta, Poonam, Bisht, Kapil and Chandra Sekar, K. 2020. Diversity of threatened medicinal plants of Indian Himalayan region, Plant Biosystems -An International Journal Dealing with all Aspects of Plant Biology, DOI: 10.1080/11263504.2020.1837278.

[13]. Mishra, D.K. and Singh, N.P. 2001. Endemic and threatened flowering plants of Maharashtra. Botanical Survey of India, Calcutta.

[14]. Nayar, M.P. and Sastry, A.R.K. 1987. Red Data Book of Indian Plants, Volume 1. Calcutta: Botanical Survey of India. 367 pp.

[15]. Nayar, M.P. and Sastry, A.R.K. 1988. Red Data Book of Indian Plants, Volume 2. Calcutta: Botanical Survey of India. 150 pp.

[16]. Nayar, M.P. and Sastry, A.R.K. 1990. Red Data Book of Indian Plants, Volume 3. Calcutta: Botanical Survey of India. $271 \mathrm{pp}$.

[17]. Nayar, M.P. and Sastry, A.R.K. 1990. Red Data Book of Indian Plants, Volume 3. Calcutta: Botanical Survey of India. $271 \mathrm{pp}$.

[18]. Patil, D. A. 2003. Flora of Dhule and Nandurbar District (Maharashtra), (Bishen Singh Mahendra Pal Singh, Deheradun, India).

[19]. Ravikanth, G. Jagadish, M.R., Vasudeva R., Uma Shaanker, R. and Aravind, N.A. 2018. Recovery of critically endangered plant species in India: need for a comprehensive approach. Current Science, Conservation of Threatened Plants of India. Special Section, Vol. 114, No. 3,10, 504-511.

[20]. Sarvalingam, Ariyan and Rajendran, Arumugam. 2016. Rare, Endangered and Threatened (RET) climbers of Southern Western Ghats, India. Revista Chilena de Historia Natural ), 89:9,1-5. DOI 10.1186/s40693-016-0058-6 
[21]. Smith., E.V. 1980. Laws and information need for listing plants. Rhodora 82:193.

[22]. Sukumaran S. and Raj A.D.S. 2007. Rare Endemic Threatened (RET) trees and lianas in the Sacred Groves of Kanyakumari district. Indian Forester. 133:1254-66.

[23]. Surveswaran, Siddharthan, Kambale, Sharad S., Srivastav, Mansa, Punekar, Sachin A., Yadav, Shrirang R. and Karanth, Praveen K. 2020. Origin and diversification of Indian Ceropegieae (Apocynaceae) and its possible relation to the Indian monsoon. Journal of Systematics and Evolution . Vol00, Issue00, pp 1-20. Institute of Botany, Chinese Academy of Sciences. doi: 10.1111/jse.12578.

[24]. Yadav S. R. 1997. Rare flowering plant species of Maharashtra, their potential values and conservation in sustainable development. Proc.
Nat. Conf. Dimen. Environ. Stress India. 1-3 Dec. 1997. 35-44.

[25]. Garud, B.D. and Shinde, Smita 2018. New additions to the flora of Nasik district, Maharashtra (India). International Journal of Botany Studies. Vol. 3; Issue 4; ISSN: 2455541X. Page No. 37-38

\section{Cite this article as :}

Sangale M. P., Kshirsagar S. R., Shinde H. P., "Studies on floristic diversity of some endangered plant species from Western Ghats of Nasik district, Maharashtra.", International Journal of Scientific Research in Science and Technology (IJSRST), Online ISSN : 2395-602X, Print ISSN : 2395-6011, Volume 8 Issue 2, pp. 278-286, March-April 2021. Available at

doi : https://doi.org/10.32628/IJSRST218235

Journal URL : https://ijsrst.com/IJSRST218235

Table 1 : List of endangered plant species recorded within the study area

\begin{tabular}{|c|c|c|c|c|}
\hline $\begin{array}{l}\text { Sr. } \\
\text { No. }\end{array}$ & Plant species & Family & Local Name & Habit \\
\hline 1. & $\begin{array}{l}\text { Ceropegia anjanerica Malpure, Kamble \& } \\
\text { Yadav }\end{array}$ & \multirow[t]{8}{*}{ Apocynaceae } & $\begin{array}{c}\text { Lahan } \\
\text { kharpudi }\end{array}$ & Herb \\
\hline 2. & Ceropegia bulbosa var. balbosa Roxb. & & Hamil & Twinner \\
\hline 3. & $\begin{array}{l}\text { Ceropegia bulbosa var. lushii (Grah.) } \\
\text { Hook f. }\end{array}$ & & Gavtya hamil & Twinner \\
\hline 4. & Ceropegia hirsuta Wight \& Arn. & & Hamil & Twinner \\
\hline 5. & Ceropegia lawii Hook. & & $\begin{array}{c}\text { Moti } \\
\text { Kharpudi }\end{array}$ & Herb \\
\hline 6. & Ceropegia media (Huber) Ansari & & $\begin{array}{c}\text { Medi } \\
\text { Kharchudi }\end{array}$ & Twiner \\
\hline 7. & Ceropegia mahabalei Hemandri & & Kharchudi & Herb \\
\hline 8. & Ceropegia sahyadrica Ansari \& Kulkarni & & Kharpudi & Herb \\
\hline
\end{tabular}




\begin{tabular}{|c|c|c|c|c|}
\hline 9. & Asparagus racemosus Willd. & Liliaceae & & Shrub \\
\hline 10. & $\begin{array}{l}\text { Chlorophytum borivilianum Sant. \& } \\
\text { Fernand. }\end{array}$ & & Kolu & Herb \\
\hline 11. & Chlorophytum bharuchii Ansari & & Musali & Herb \\
\hline 12. & Chlorophytum tuberosum (Roxb.) Baker & & Safed musali & Herb \\
\hline 13. & Dipcadi concanensis (Dalz.) Baker & & $\begin{array}{r}\text { Konkan } \\
\text { dipkadi }\end{array}$ & Herb \\
\hline 14. & Gloriosa superba L. & & Kal-lavi & Herb \\
\hline 15. & Dendrobium barbatulum Lindl & Orchidaceae & Vasant abri & Epiphyte \\
\hline 16. & Eulophia ochreata Lindl & & Amarkand & Herb \\
\hline 17. & Habenaria suaveolens Dalz. & & Habe abri & Herb \\
\hline 18. & Habenaria panchganiensis Sant. \& Kap. & & $\begin{array}{l}\text { Panchgani } \\
\text { habeabri }\end{array}$ & Herb \\
\hline 19. & Begonia phrixophylla Blatt. \& McC. & Begoniaceae & Shimpli & Herb \\
\hline 20. & Begonia trichocarpa Dalz & & $\begin{array}{c}\text { Pandari } \\
\text { shompali }\end{array}$ & Herb \\
\hline 21. & Thalictrum dalzellii Hook. & Rananculaceae & Swetamber & Herb \\
\hline 22. & Maytenus rothiana (Lawson) Lobreau & Celastraceae & Lokhandi & Shrub \\
\hline 23. & Cayratia trifolia (L.) Domin & Vitaceae & Ambatvel & Climber \\
\hline
\end{tabular}




\begin{tabular}{|c|l|c|c|c|}
\hline 24. & Vigna khandalensis (Sant.) Raghavan & Fabaceae & Budmug & Herb \\
\hline 25. & Sonerila scapigera Dalzell & Melastomataceae & Sonerila & Herb \\
\hline 26. & Neanotis sahyadrica Billore \& Mudaliar & Rubiaceae & Kapar & Herb \\
& & & chandani & \\
\hline 27. & Canscora diffusa (Vahl) var. tetraptera R. & Gentianaceae & Kilwar & Herb \\
\hline 28. & Leucas deodikarii Billore \& Hemadri & Lamiaceae & Herb \\
\hline 29. & Zingiber diwakarianum R. Kr. Singh. & Zingibearaceae & Shindvan & Herb \\
\hline 30. & Arisaema sahyadricum Yadav et al. & Araceae & Saapkand & Herb \\
\hline
\end{tabular}

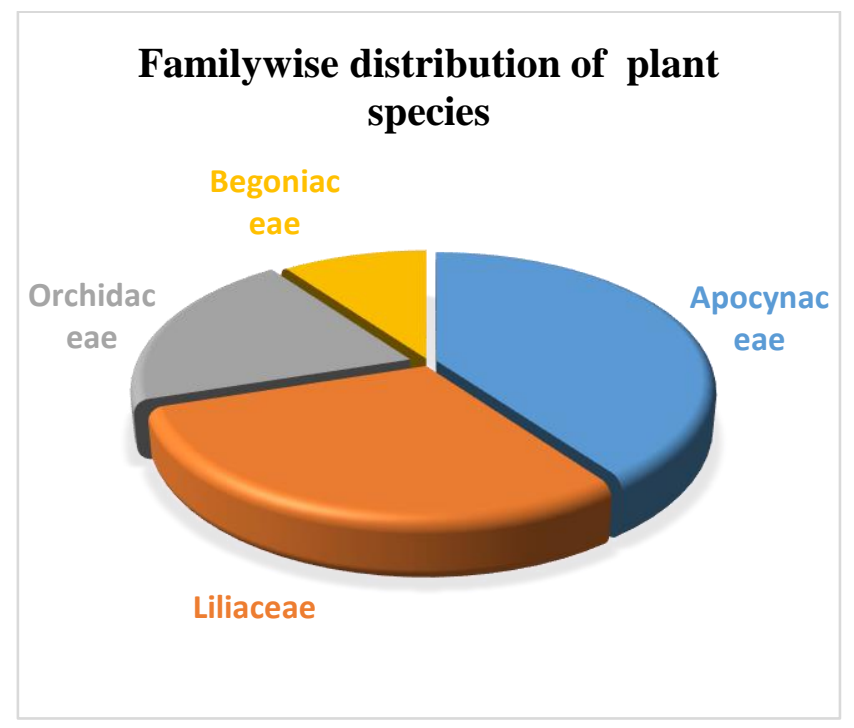

Fig. 2 - A Familywise distribution of plant species

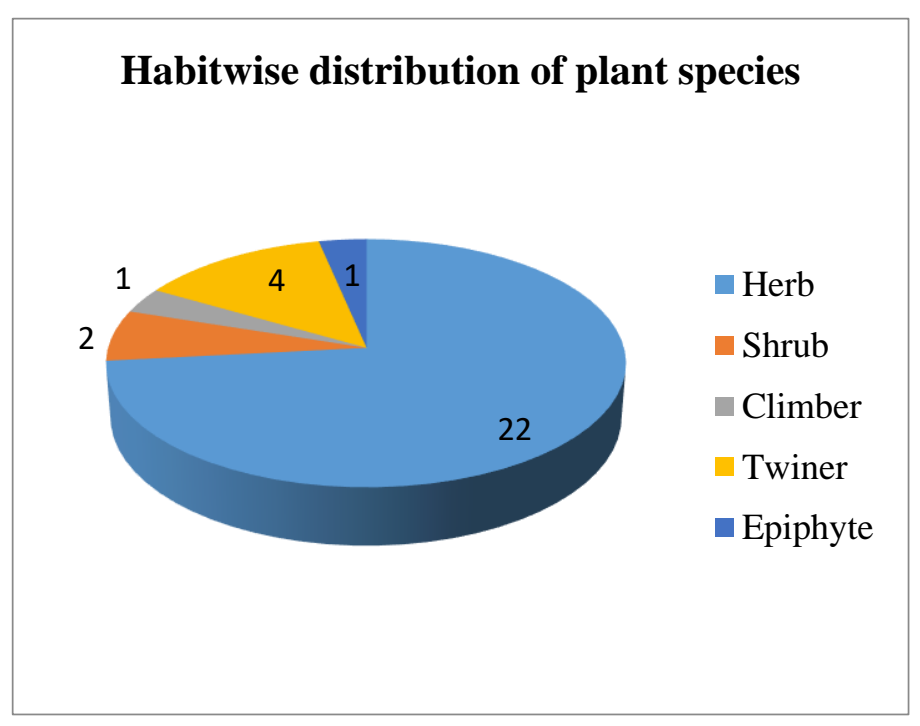

Fig.2 B. Habit wise distribution of plant species 
Sangale M. P. et al Int J Sci Res Sci \& Technol. March-April-2021, 8 (2) : 278-286

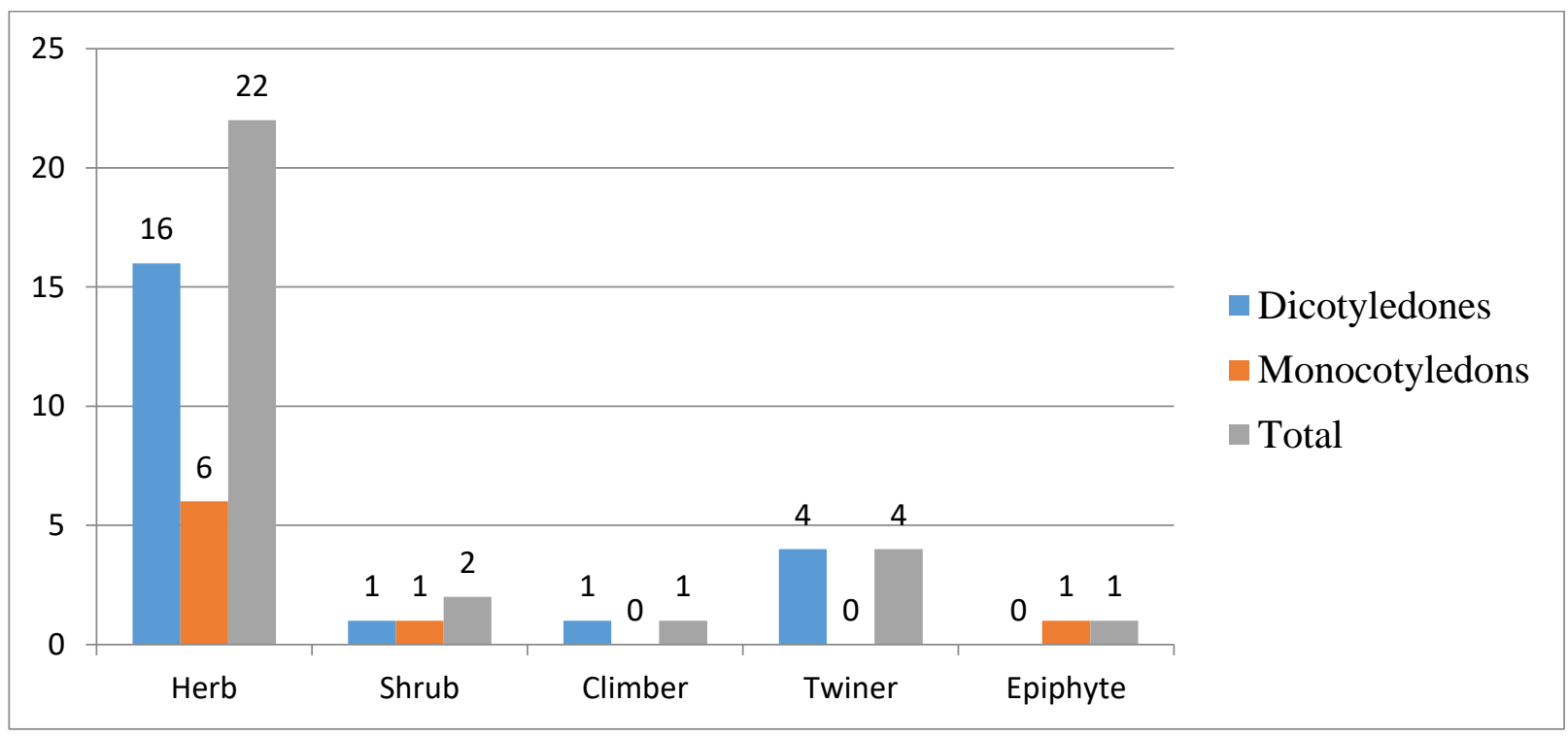

Fig.2-C Habit wise distribution among Dicot and Monocot plant species

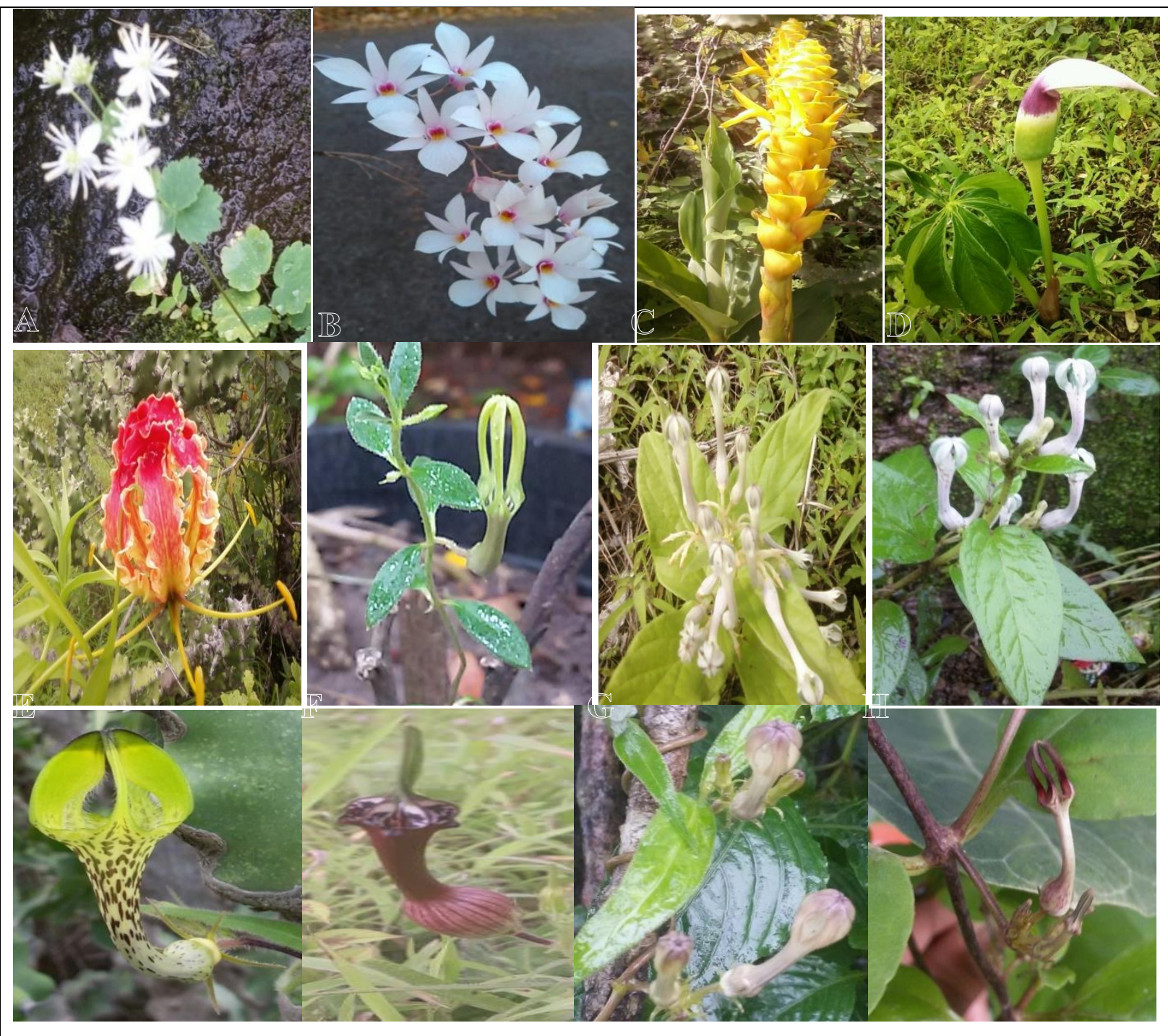




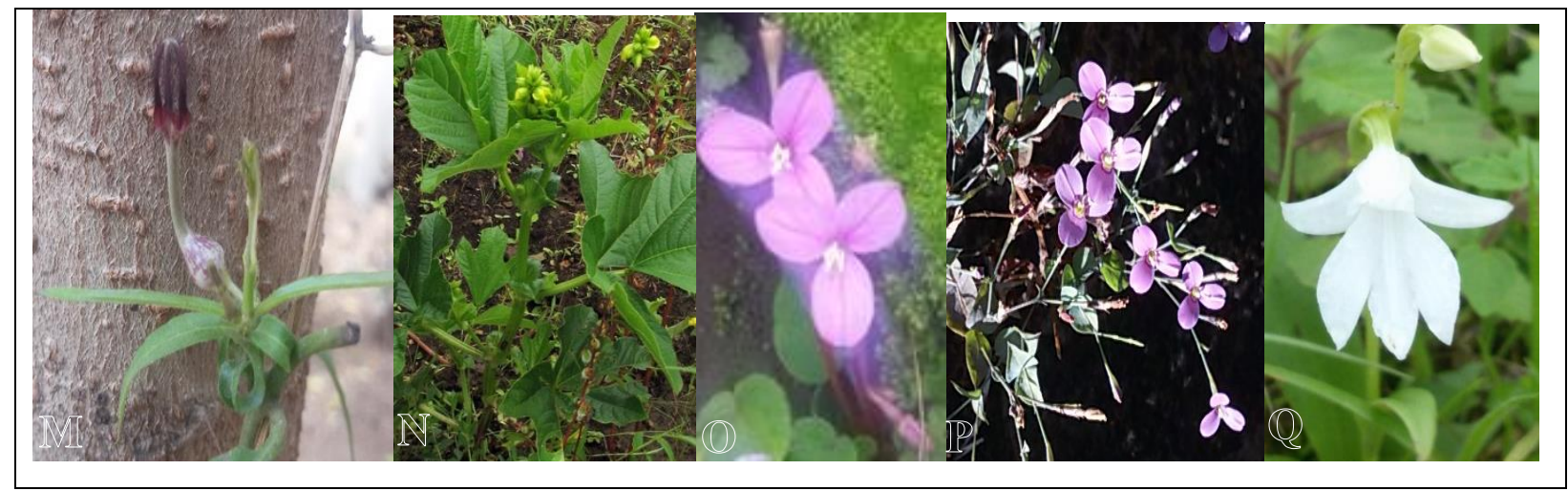

A- Thalictrum dalzellii, B- Dendrobium barbatulum, C- Zingiber devakarianum , D- Arisaema sahyadricum E- Gloriosa superba, F- Ceropegia anjanerica, G- Ceropegia sahyadrica, H- Ceropegia lawii , I- Ceropegia hirsuta, J- Ceropegia mahabalei, K- Ceropegia media, L-Ceropegia bulbosa var. balboas M- Ceropegia bulbosa var. lush,i N- Vigna khandalensis, O- Sonerila scapigera, P-Canscora diffusa, Q- Habenaria panchganiensis

Fig. 3. Photo plate showing floral diversity of recorded endangered plant species. 